\title{
Business tourism in Porto: an empirical investigation of its potentialities and development challenges
}

\author{
Micaela Pinho and Jorge Marques
}

\begin{abstract}
Purpose - The purpose of this paper is to explore the potentialities and weaknesses of the city of Porto (Portugal) in the business tourism segment in order to ensure and develop a destination's business tourism strategy position.

Design/methodology/approach - Data were collected through the participation of 28 experts living/working in Porto in a three-round Delphi exercise. Experts should identify the main straights, weaknesses and opportunities of the city for the business tourism development.

Findings - The main results show that the city's potential to become landmark destination in the business tourism sector far outweighs its limitations. With measures aimed to improve the functionality of the business tourism segment and marketing strategies to increase external promotion, Porto meets the conditions to become an excellent business tourism destination.

Originality/value - Many studies have been conducted from the perspective of leisure tourism; few have been conducted from the perspective of the business tourism and none have been conducted from the perspective of the business tourism in the city of Porto. This research fills a gap in the literature relating to the practice of meeting industry. It represents the first attempt to elicit stakeholders opinions about important issues related to the development of business tourism in the city. The results of the study provide a more informed and systematic basis on which to develop the business tourism segment in Porto.
\end{abstract}

Keywords Portugal, Porto, Attitudes of stakeholders, Business tourism, Meeting

industry Paper type Research paper

\section{Introduction}

Inbound tourism is one of the main contributors to the economic development of many countries (Pablo-Romero and Molina, 2013). The business tourism segment, in particular, plays a key role in tourism-led economic growth (Tan and Tsui, 2017). The travel and tourism industry is nowadays one of the world largest economic sectors supporting one in ten jobs worldwide and generating 10.4 per cent of world gross domestic product (WTTC, 2019). In 2018, the international tourist arrivals grew even more than the global economy -6 vs 3.7 per cent (UNWTO, 2019a, b). Europe was the largest receiver of tourist $(718 \mathrm{~m})$ recording an increase of 6 per cent over an exceptionally strong 2017 (UNWTO, 2019a, b). This growth was driven by Southern and Mediterranean Europe (+7 per cent), Central and Eastern Europe (+6 per cent) and Western Europe (+6 per cent) (UNWTO, 2019a, b).

This pattern is, however, expected to change since in 2019, the global economic slowdown, the uncertainty related to the "Brexit", as well as geopolitical and trade tensions lead the World Tourism Organization to forecast international arrivals to grow only 3-4 per cent (UNWTO, 2019a, b). Moreover, many Mediterranean tourism destinations are now in the late maturity stage of their product life-cycle and are expected to enter the declining phase which will convert them into less competitiveness destination. Thus, it becomes increasingly important that these countries develop new tourism segment to prevent the losses expected in the traditional tourism 
segment of leisure. Business tourism segment is a possibility that has received growing interest from many tourism managers and has achieved significant growth in recent years. In 2017, vacations, recreation and leisure travel accounted for 53 per cent of the total number of international arrivals, whereas business travel occupied the third share accounting for 13 per cent of the total international arrivals (UNWTO, 2019a, b). Business travel spending (inbound and domestic) generated 22.5 per cent of direct travel and tourism gross domestic product worldwide and was forecasted to increase by 3.8 per cent in 2018 (WTTC, 2019).

Business tourism or meeting industry (terms we will use as interchangeable hereinafter following) is a form of tourism for commercial, governmental and/or educational purposes with the recreational (leisure) part as a secondary motivation. It is widely known that the duration of the stay in the destination is extended beyond the duration of the business event/professional requirement so that the visitor can visit the region and its attractions. Thus, business tourism reduces the typical seasonality of the leisure tourism by prolonging the tourism season and increasing the occupancy rate of accommodation. Besides, the possibility of returning this time in a context of tourist leisure and/or the promotion of the place where the event took place in the circle of influence reflects the potential of the business tourism segment for local and regional development. Therefore, the business tourism segment is not only an alternative to leisure tourism but also a complement: it forms the image of a destination and, as such, has a multiplicative effect on economic and social components of the destination. In sum, the low seasonality, the higher revenue of accommodation and meeting venues, the high demand for food and beverage, the boost in leisure tourism and also the controlled environmental impact and the relative resilience to economic crises are factors that make business tourism so attractive to destinations.

Although considerable academic attention has been paid for understanding the international holiday tourism and tourism aggregate across visit purposes, only scant attention has been paid to business tourism segment. This is of concern insofar as unlike leisure tourism, which is a business-to-consumer activity, business tourism is a businessto-business activity with organizational perceptions more commercially oriented. In the last two decades, there is some international literature on business tourism determinants and market development (Bradley et al., 2002; Ivancevich et al., 2003; Kulendran and Wilson, 2000; Kulendran and Witt, 2003; Hankinson, 2005; Lu and Peeta, 2009; Gustafson, 2012; Mason, 2002; Nicula and Elena, 2014; Reshetnikova, 2017; Smagina et al., 2017; Carvalho et al., 2018) and also few country-specific studies: Portugal (Almeida, 2010; Marques and Santos, 2016, 2017a, b); Poland (Zontek et al., 2018); New Zealand (Tsui et al., 2018); Africa (Tichaawa, 2017); Republic of Ireland and Wales (Heather, 2017); Croatia (Gračan and Rudančic'-Lugaric, 2011); Norwegian (Denstadli, 2004); China ( Jang et al., 2003), Wales (Wootton and Stevens, 1995) and Macau (Dioko and Whitfield, 2015).

Nevertheless, no study to date has assessed the potential of the city of Porto - second largest Portuguese city, located in the north of the country, and one of the major urban areas of the Iberian Peninsula, for the development of business tourism. To the best of our knowledge, only a few studies have analyzed the business tourism in Portugal but it has focussed in evaluating its potential in Central Region of the country, territories characterized by lower urban density and lower supply of facilities and services (Marques and Santos, 2016, 2017a, b).

The research presented in this paper seeks to overcome this limitation by promoting a reflection around the strategic planning to develop the meeting industry in the city of Porto. Thus, we explore the opinions of individuals who have interest or concern in Porto's business tourism (stakeholders) and therefore are directly involved in Porto tourism sector, to make an SWOT analysis, i.e. to identify the strengths, weaknesses, threats and opportunities related to the development of business tourism in this territory.

\section{Overview and study motivations}

This research is not only novel but also timely for the city of Porto, in particular, and for the entire country, in general. Tourism has been an important driver of Portuguese economic growth mainly due to its significant impact on the trade balance. The weight of tourism receipts in 
exports has been quite significant, with continuous growth since 2012 (Figure 1). In 2016, Portugal won 24 awards and many tourist enterprises won awards, with Turismo de Portugal considered the deemed Europe's Leading Tourist Board (Almeida et al., 2019). In 2017, Portugal was the 14th most competitive tourist destination in the world among 136 countries, the 17 th country in the world in the arrival of tourist and reached the 21 st position in tourist receipts (UNWTO, 2019a, b). These receipts represented, in 2018, 8.2 per cent of the Portuguese gross domestic product and have increased 9.6 per cent in relation to 2017 (a year of record growth: +91.5 per cent) (Turismo de Portugal, 2019). The majority of inbound tourist ( 81 per cent) came from European countries with a growing trend of intercontinental markets (mainly from the American continent) (INE, 2019). During the financial crisis (2010-2014) tourism not only helped the economic recovery but also prevented the recession from being more pronounced. However, we should bear in mind that the conflicts in the Middle East (Arab Spring) had a great deal of responsibility in this Portuguese tourism inbound. The Middle East is, however, already at peace and a relocation of tourists back to these historic destinations is becoming evident. Therefore, decisions makers in Portugal should take advantage of the visibility and projections gained so far and bet seriously in the tourism business segment to attract business travellers and offset the potential loss of leisure tourists.

This study is particularly relevant for four main reasons. First, Portugal is already a reference destination in the meeting industry, mainly because it has entered the circuit of major events, examples of which are the International Rotary Convention, held in Lisbon in 2013; Web Summit, held in Lisbon since 2016 (will remain in Portugal until 2028); Great Wine Capitals Global Network, held in Porto in 2017 and Eurovision Song Contest held in Lisbon, in 2018. This growing dynamic explain that Portugal reached, in 2017 and according to the latest data of ICCA (2018), the world's top 11 most popular destination for international events (jumping one place). In this ranking, Lisbon occupied the 9th place (remaining the most well-positioned Portuguese city), whereas Porto registered the highest rise, climbing eight places to the 34th position (ICCA, 2019). Figure 2 shows the trend of the meeting industry in Portugal, Lisbon and Porto since 2003. It is worth mentioning that the number of meeting held in Porto increased the most during the 14-year period accounting for a 300 per cent increase compared to the 96 per cent increase in Lisbon and 118 per cent in the whole country.

Second, at the governmental level, there has been a focus on developing strategies to promote and streamline business tourism through the National Strategic Plan for Tourism (PENT, 2007) and the Tourism Strategy 2027 (ET, 2017) ( for a detailed description, see Araújo, 2017). More recently, the Portugal Tourism (National Tourism Authority integrated in the Ministry of Economy) has just launched a digital platform - "Meeting in Portugal Platform", whose objective
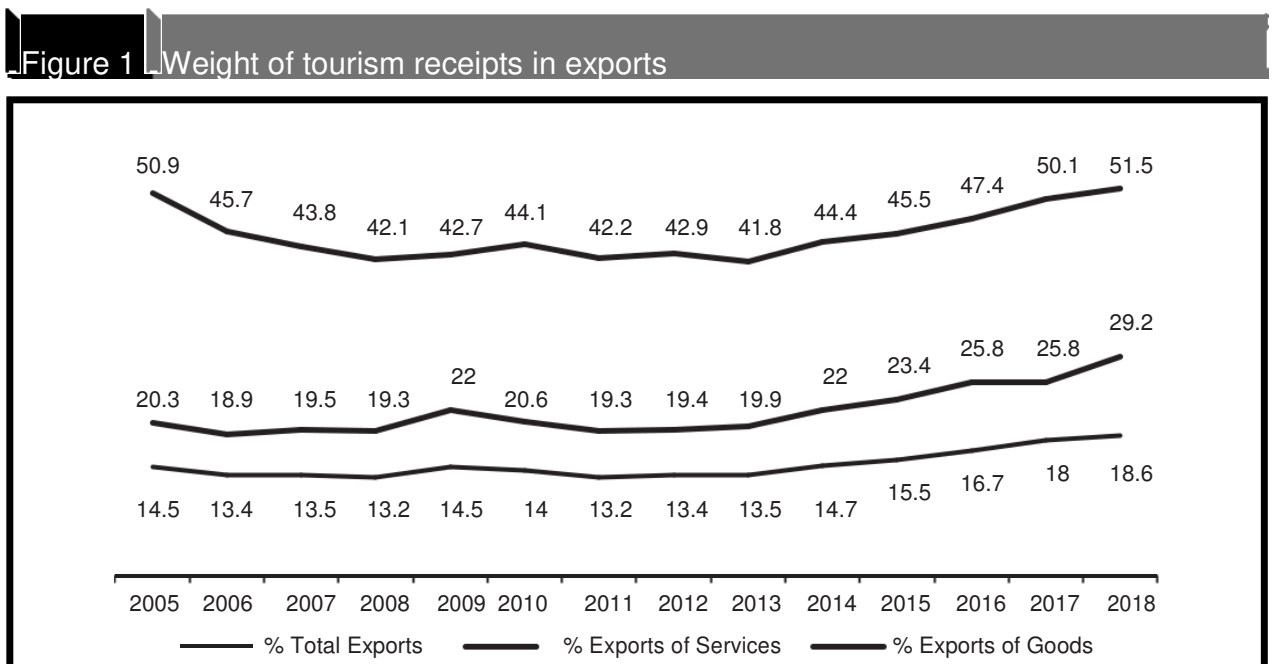

Sources: Authors based in data from Banco de Portugal (2019) and Turismo de Portugal (2019) 


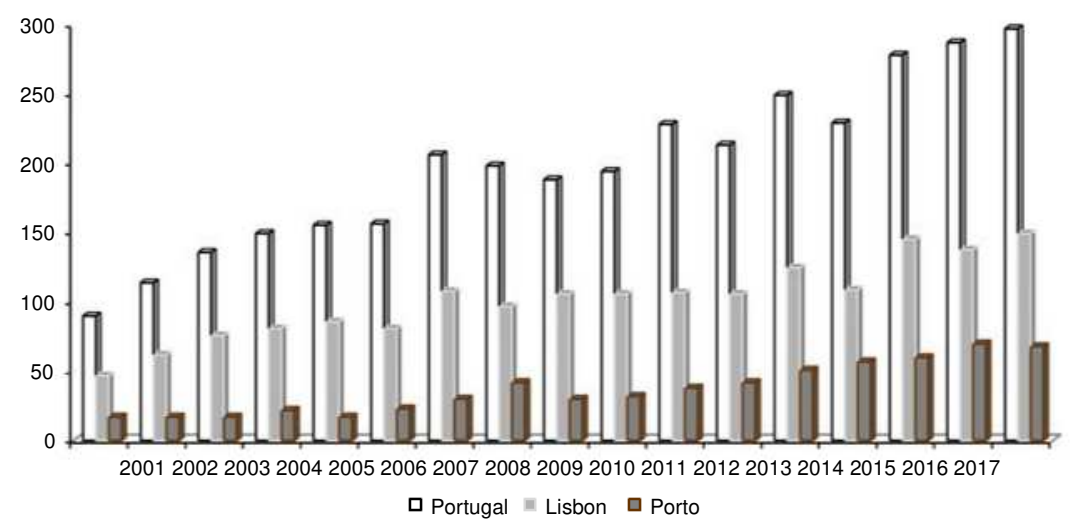

Source: Authors based on data from the ICCA reports

is to promote the country as a destination of choice for events and conferences, with a special focus on the international market and the corporate market. Third, the city of Porto brings together a set of potentials capable of promoting on its own, business tourism along with urban or city tourism. The city is geographically well located on the banks of the River Douro and has rich historical and cultural heritage being pointed in 2001 European Capital of Culture; Porto's historical centre is a World Heritage Centre added by the United Nations Educational, Scientific and Cultural Organization's (UNESCO) in 1996; the Porto's wines are recognized internationally; the nightlife areas in the historical centre are a reference for who wants to have fun at affordable prices; Porto has a modern transport and communication network and is very close from surrounding country areas with beautiful landscapes. Porto was considered for the third time the Best European Destination by the Best European Destinations Agency. Porto was the only Portuguese city to win the award and the first to win it more than once (Furthermore, in 2018, Porto entered the list of the 100 most visited cities in the world, joining Lisbon as the representative of Portugal in the ranking prepared by Euromonitor International (Euromonitor International, 2018). Porto debuted in the top 100, occupying 96th place (while the Portuguese capital won a place and ascended to 62nd position). Between 2012 and 2017, Porto was on 42 place in this "ranking" (Euromonitor International, 2018). Since the city of Porto has been a highly popular tourist area in the last years, why not mix business with pleasure? Finally, Porto has three important referenced venues - Exponor Exhibition Center (Porto International Fair), Alfândega Porto Congress Centre which is nationally and internationally recognized and awarded by several institutions[1] and the Rosa Mota Pavilion/ Crystal Palace. Currently, the requalification of the Crystal Palace has been under discussion in order to modernize and expand its facilities.

In sum, Porto is a very favourable destination and should take this opportunity to foster its business tourism segment. Thus, with this exploratory study, we intend to understand the best way to accelerate the business tourism development in the city. Following a strategic planning technique, we explore the strength, weakness, threats and opportunities identified by a group of stakeholders operating in the Porto. The study here presented intends to contribute to the development of business tourism in the city of Porto.

\section{Methods}

\section{Research design}

To meet the study's aim, a qualitative analysis through a Delphi technique was undertaken. The Delphi technique is a communication method based on the principle that decisions from a 
structured group of individuals are more accurate than those from unstructured groups (Rowe and Wright, 2001). Indeed, the critical opinion of specialists or experts in a particular area is achieved in successive rounds until a consensus has been reached (Dalkey, 1969; Landeta, 2006). Participants are asked to respond to questions without coming into face-to-face contact with each other. Panel participants are not identified to each other during the course of the study and comments of the panellists are always included anonymously in each stage of the inquiry. This process has the advantage of elimination of all interpersonal dynamics that tend to exist in face-to-face decision making.

In recent years, Delphi techniques have been widely used in the tourism field (Lin and Song, 2015 for a review).

\section{Participants}

The eligibility criteria of this study dictate that participants should cumulative meet the following requirements: have professional or academic experience in the tourism sector and/or in the specific business tourism segment; develop their professional and/or academic activity in Porto; and hold a vast knowledge of the city of Porto. We constituted a homogeneous and balanced panel of experts from different areas to collect different perspectives. After a careful research of the potential stakeholders that fulfilled the eligible criteria, an invitation letter was send, by email, to each of the 55 stakeholders identified. In total, 28 agreed to participate ( final response rate of 51 per cent), thus constituting the initial panel. Participants in the panel were experts from seven different areas, namely, four academics in the field of tourism; four from business and trade associations; four venues representatives; five accommodation and travel agents; four cultural, leisure and recreation suppliers; four from public and institutional entities; and three tourism managers. Their age ranged from 30 to 53 years old with a mean work experience of 18 years. There were 18 males and 10 females and all participants completed, at least, the higher education. Most of the experts (85 per cent) have never worked abroad but all reported attending often training activities in the tourism sector.

\section{Procedures and Delphi rounds}

The study involved three rounds of web-based questionnaires, all of them conducted by e-mail and undertaken between September of 2018 and January of 2019. The questionnaire comprised two sections - A and B. The study here presented focussed only in Section A questions. Therefore, only this description will be detailed. The data collection proceeded in three rounds, as follows (Figure 3). In Round 1, participants were asked four questions (one closed question and three open-ended questions) concerning the business tourism segment in the city. They were asked to identify whether the business tourism is an important sector for the Porto's economic development (closed question answered trough a five-point Likert scale: 1 nothing important to 5 very important) and justify their answer; the factors that make the city of Porto an attractiveness destination for business development; the difficulties/limitations for the development of business tourism in Porto; and the opportunities (strategic measures) for the development of business tourism in Porto. In Round 2, the lists of opinions/suggestions obtained from Round 1 were compiled and organized. Participants were then asked to indicate on a fivepoint scale (not important, slightly important, important, moderately important and very important) the level of importance attached to each statement. Participants could also indicate additional items to the list. In Round 3 - the final round - participants were shown the results of Round 2 were there was a tie in the answers. For these cases, participants were asked, once again, on the same five-point scale the importance attached to each statement.

\section{Results}

The complete list of opinions from Round 3 (considered important or very important) is summarized in Figure 4. It should be noted that the sample size decreased between the round from the first to the second round, two participants were missed (sample size 26) and, from this to the third round one more respondent did not fulfil the questionnaire ( final sample size 25). 


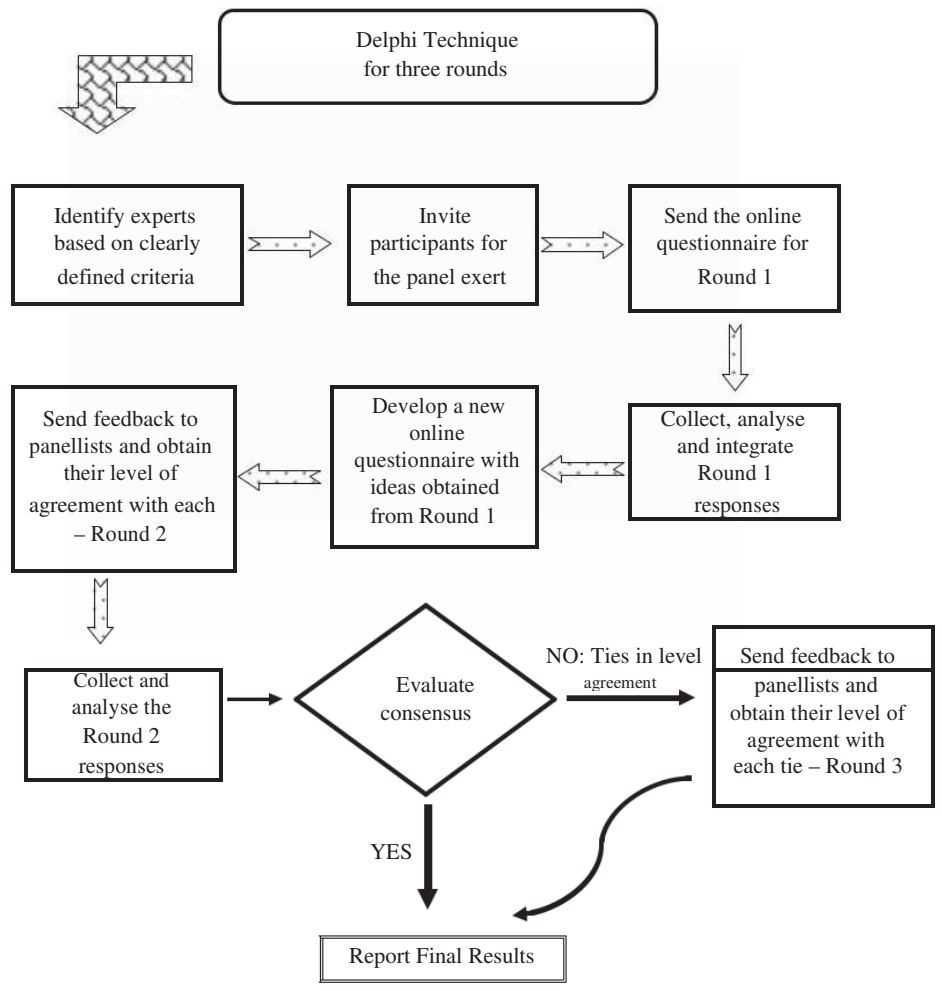

Note: The number of rounds was limited to 3

\section{Figure 4 Overview of panel experts opinions concerning business tourism in the city} of Porto (sample size 25) (SWOT analysis)

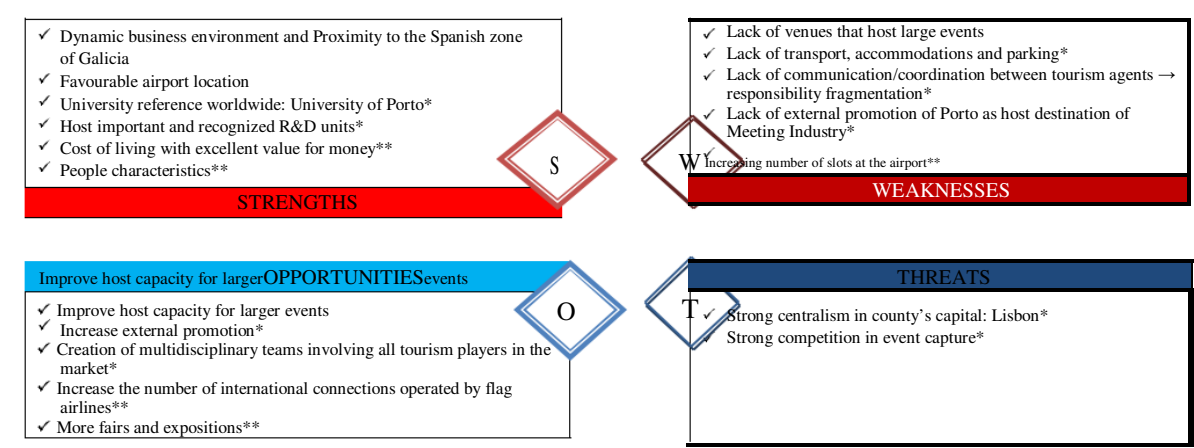

Notes: Statements in bold are those with greater number of mentions ((Greater than or equal to 19 mentions (75-100 per cent)); statements with * are mentioned between 13 and 19 times (50-75 per cent); statements with $* *$ are mentioned between 6 and 13 times (25-50 per cent)

\section{Relevance/Importance of business tourism to Porto}

The findings from the first question revealed that the experts inquired were unanimous in considering the business tourism an important (17.8 per cent) or very important (82.2 per cent) driver of the city's economic development. All participants considered the meeting industry a 
complement to leisure tourism, a way to prolong the stay and a way to counteracting seasonality. The final results from this question were obtained in the first round because the question was closed. The sample size was 28 (results of the first question are not summarized in Figure 4 since it was a closed question).

\section{Strength of Porto for business tourism development}

When asked about the potential of the city to attract and foster the business tourism segment (second question), most experts indicated the dynamic business environment in Porto and the business connection with the rest of the northern territory. In this regard, some participants mentioned the proximity of Porto to the Spanish zone of Galicia and how economic cooperation interests between both regions have been discussed (especially after "Brexit"). The favourable airport location was another attractiveness pointed by the majority of the respondents. Actually, the airport is $11 \mathrm{~km}$ from the city with direct access by metro. In 2019, the airport serves 78 direct destinations and operates with 21 airlines, on a regular basis. Furthermore, the airport was considered, in 2015, the third Best European Airport by Airport Council International (repeating its position in 2013). The University of Porto located in the city and recognized worldwide as a university reference centre (by the Academic Ranking World Universities) was also mentioned by almost twothirds of respondents as a promoter of the meeting industry for its ability to attract international academic conferences but also for being a research and development (R\&D) centre - Science of Technology Park of University of Porto (UPTEC). In fourth place, participants stressed the location of important and recognized R\&D units, operated also by private entities. Finally, the living cost with excellent value for money and Portuguese sympathy, hospitality and organizational capacity were also recognized (by 40 per cent of respondents) as an advantage of the city for the business tourism segment.

\section{Weaknesses and threats of Porto for business tourism development}

The answers to the third question identify five weakness and two treats of and to the meeting industry development in the city. The existence of few venues with capacity to organize large events was a limitation felt by all participants. Also often mentioned (by 72 per cent of participants), as a handicap to the development of business tourism, was the lack of transport, accommodations and parking especially during high season. More than half of respondents mentioned that the disunity among organizations and the consequent fragmentation of responsibilities creates a barrier to the development of the business tourism segment. Participants also cited (though not as much as the previous ones) the lack of dynamics in promoting the meeting industry and difficulties created by the existence of many slots at the airport. The strong competition that characterizes the actual meeting industry and the strong centralism in the country's capital - Lisbon (where the supply of accommodations and venues is more developed) were seen as serious threats to the development of the business tourism segment in Porto.

\section{Opportunities for the development of business tourism in Porto}

In relation to the measures that could/should be adopted to foster the business tourism development in the city ( fourth question), participants pointed (by increasing order of importance) the need to improve venues facilities in order to: compete with Lisbon and other European cities in the realization of bigger events; and increase Porto's destination projection. Also, widely suggested (by 60 per cent of experts inquired) was the bet on marketing strategies to increase the city visibility as an event hosting destination. Notwithstanding the recognized dynamic of the Porto's airport, almost half of the participants understood that there should be more international connections operated by flag airlines. The creation of a multidisciplinary team (with all tourism agents in the market) so that venues could be sold together or in cooperation was an idea suggested by 64 per cent of the experts inquired. One last proposal indicated by two-fifths of the participants was the need to hold more fairs and expositions to project the city as a destination worldwide. 


\section{Discussion and conclusion}

This study reflects part of a wider project on the research of business tourism in the city of Porto. The main goal was to understand the city's strength, weaknesses, threats and opportunities as a tourism business destination and therefore propose strategic measures for its development. A qualitative methodology - Delphi technique - was used in an attempt to guide a group of stakeholders from Porto towards some consensus regarding policies that should be pursued, in the short term, to convert the city in a destination brand image in business tourism. The findings suggest that experts share similar opinions. The business tourism segment was recognized as of strategic interest for the economic development of Porto and an important complement to leisure tourism.

Participants identified the airport privileged localization and its dynamics as a possible determinant of Porto's business tourism. Empirical evidence confirms this strength by revealing that business travellers are very sensitive to access time to airports (Marcucci and Gatta, 2012) while are relatively price inelastic (Lu and Peeta, 2009) and therefore prefer to travel with flag airlines (O'Connell and Williams, 2005). Moreover, business travellers tend to prefer flag airlines connection and tend to prefer flying with what seems to in accordance with the "time is money" proverb in the business world. Still, air congestions at the airport or frequent delays may deter business tourist from travelling. It is well documented that accessibility is a key determinant and a brand image attribute of a business tourism destination (Nicula and Elena, 2014; Hankinson, 2005). The strong business dynamic in Porto, the host of R\&D units were also enhanced as Porto' business tourism determinants. This perception is confirmed by international evidence which shows that economic activity and destination brand image are positively related (Hankinson, 2005). The relatively low cost of living in the city and peoples characteristics were also pointed as strong attractiveness for business travellers. This expert's opinion does not seem, however, to be consensual since some studies indicate that the destination prices (measured through the origin-destination country pair's relative consumer price index) are less likely to influence the number of business travel than trade volumes (Kulendran and Wilson, 2000; Turner and Witt, 2001). Yet, the role of people and the culture of the resident population were identified as relevant attributes for business and leisure tourism (Hankinson, 2005; Vengesayi et al., 2009; Reitsamer and Brunner-Sperdin, 2017).

Our study also found barriers, in the city, that affect business tourism development. The main difficulties identified by respondents were related to functional conditioning (business tourism facilities) and management conditioning (individualized rather than cooperative management among tourist agents and insufficient external promotion). Therefore, to circumvent these limitations while enhancing the attributes of the city to become a destination brand image, it would be highly important that regional and national tourism authorities' develop policies that improve the functionality of the segment. Measures that promote the creation of venues facilities, accommodations and strengthen relations between the different tourist agents would be of regional interest. Furthermore, the Porto's strengths identified in this study provide a more informed and systematic basis on which to develop a destinations positioning strategy. Business marketers may use the advantages held by the city to develop strategic brand and marketing strategies to promote external promotion and create an identity for Porto as a business tourism destination. Moreover, marketers and tourist managers should take advantage of the positive image that Porto has gained over the last few years in leisure tourism and capitalize potential synergies by managing both areas together. These measures would certainly help to overcome the strong international competition in event capture. At the national level, the government should take concrete measures to reduce centralism in the capital of the country otherwise the inequalities will remain in a country as small as Portugal.

One key strength of our study is being the first attempt to collect evidence on stakeholders' opinions about the city's potential to develop the segment of business tourism. A second strength is the ability to increase the literature in the area of business tourism which remains scarce.

An inevitable drawback of this study is the use of Delphi technique to collect data. We are aware that despite it widespread use in tourism studies some Delphi's methodological issues remain unresolved, such as the definition of what constitutes a correct panel expert or the best way to 
present feedbacks. Besides these limitations, there may also be a sample size limitation. In a review of tourism studies using the Delphi methodology, it was possible to conclude that the sample size ranged from 6 to over 900 (Lin and Song, 2015). It seems, however, that the sample size for constructing a Delphi panel is not a statistically bound decision and good results can be obtained by a comparatively small group of homogeneous experts (Ziglio, 1996). There is empirical evidence suggesting that reliable outcomes can be obtained of a Delphi panel consisting of a relatively small number of experts (23) selected via strict inclusion criteria (Akins et al., 2005). It is our contention that these drawbacks are overcome by the contribution of this study.

In follow-up research, it would be useful more specifically to investigate the opinion of travellers who have at some time coming to Porto in business. It would also be useful to conduct further international comparative research to compare business traveller's views across a range of different countries cities with similar characteristics in order to explore cultural differences.

Overall, our findings suggest that the city of Porto holds a great potential for the meeting industry, recognized by main stakeholders, that has been under-exploited so far. We hope that this study has contributed to sensitize the national authorities and decision makers to the need to invest in this particular segment of the tourism industry. Furthermore, it is our contention that this study highlights also the potentials of the city of Porto for urban tourism bringing value to city tourism practitioners.

\section{Note}

1. In 2006, 2011-2013 and 2015, it was considered the Best Congress Centre by Gal de Eventos/Expo Events. In 2013 and 2014, it was recognized as the Best Congress Space by the Publicturis Portugal Travel. In 2014 and 2015, it was considered the Europe's Best Meeting \& Conference Centre by Business Destination.

\section{References}

Akins, R., Tolson, H. and Cole, B. (2005), "Stability of response characteristics of a Delphi panel: application of bootstrap data expansion”, BMC Medical Research Methodologies, Vol. 5 No. 37, doi: 10.1186/1471-2288-5-37.

Almeida, M. (2010), Imagen de Portugal en el turismo de negocios. Análisis empírico en las ferias y reuniones internacionales. Dissertação de Doutoramento. Faculdade de Ciências Económicas e Empresariais. Universidade da Extremadura.

Almeida, F., Silva, O. and Amoêdo, N. (2019), "Urban tourist motivations in the city of Porto", Journal of Tourism \& Management Research, Vol. 4 No. 2, pp. 445-62.

Araújo, L. (2017), "Portuguese tourism strategy 2027 Leading the tourism of the future", Worldwide Hospitality and Tourism Themes, Vol. 9 No. 6, pp. 646-52.

Banco de Portugal (2019), "Boletim económico", Dezembro, available at: www.bportugal.pt/sites/default/ files/anexos/pdf-boletim/be_dez2018_p.pdf (accessed 12 April 2019).

Bradley, A., Hall, T. and Harrison, M. (2002), "Selling cities: promoting new images for meetings tourism", Cities, Vol. 19 No. 1, pp. 61-70.

Carvalho, P., Márquez, M. and Díaz-Méndez, M. (2018), "Policies to increase business tourism income: a dynamic panel data model", Journal of Convention \& Event Tourism, Vol. 19 No. 1, pp. 6382, doi: 10.1080/15470148.2017.1380546.

Dalkey, N. (1969), The Delphi Method: An Experimental Study of Group Opinion, Rand Corporation, Santa Monica, CA.

Denstadli, J. (2004), "Impacts of videoconferencing on business travel: the Norwegian experience", Journal of Air Transport Management, Vol. 10 No. 6, pp. 371-6.

Dioko, L. and Whitfield, J. (2015), "Price competitiveness and government incentives for simulating the meetings industry: a critical look at the case of Macau", International Journal of Event and Festival Management, Vol. 6 No. 1, pp. 39-53.

ET (2017), "Estratégia Turismo 2027", Liderar o turismo do futuro. Ministério da Economia e da Inovação. Turismo de Portugal, Lisboa, available at: estrategia.turismodeportugal.pt/sites/default/files/Estrategia Turismo_Portugal_ET27_0.pdf (accessed 1 April 2019). 
Euromonitor International (2018), "Country report: flows in Portugal - tourism flows in Portugal", available at: www.euromonitor.com/tourism-flows-in-portugal/report (accessed 15 May 2019).

Gračan, D. and Rudančic'-Lugaric, A. (2011), "Business tourism: modern form for improvement of the competitiveness of Croatian tourism", EkonomskaMisao i Praska, Vol. 20, No. 2, pp. 579-90, available at: https://hrcak.srce.hr/75573 (accessed 5 February 2019).

Gustafson, P. (2012), "Managing business travel: developments and dilemmas in corporate travel management", Tourism Management, Vol. 33 No. 2, pp. 276-84.

Hankinson, G. (2005), "Destination brand images: a business tourism perspective", Journal of Services Marketing, Vol. 19 No. 1, pp. 24-32.

Heather, S. (2017), "Business tourists' perceptions of nation brands and capital city brands: a comparison between Dublin/Republic of Ireland, and Cardiff/Wales”, Journal of Marketing Management, Vol. 33, Nos 9-10, pp. 817-34.

ICCA (2018), "The International Association Meetings Market 2017", International Congress \& Convention Association Statistics Report, Country and City Ranking, Public Abstract, available at: www.iccaworld.org/ dcps/doc.cfm?docid=2241 (accessed 12 February 2019).

ICCA (2019), "The International Association Meetings Market 2016", International Congress \& Convention Association Statistics Report, Public Abstract, available at: www.iccaworld.org/dcps/doc.cfm?docid=2241 (accessed 30 April 2019).

INE (2019), "Instituto Nacional Estatística", Statistics Portugal. Boletim Mensal de Estatística. Dormidas na Hotelaria (estabelecimentos hoteleiros, aldeamentos e apartamentos turísticos e quintas da Madeira), Alojamento Local, Turismo no Espaço Rural e Turismo de Habitação, Lisboa, available at: www.ine.pt/xportal/x main?xpid=INE\&xpgid=ine_publicacoes\&PUBLICACOESpub_boui=268267532\&PUBLICACOESmodo=2 (accessed 10 March 2019).

Ivancevich, J., Konopaske, R. and Defrank, R. (2003), "Business travel stress: a model, propositions and managerial implications", Work and Stress, Vol. 17 No. 2, pp. 138-57.

Jang, S., Yu, L. and Pearson, T. (2003), "Chinese travellers to the United States: a comparison of business travel and visiting friends and relatives", Tourism Geographies, Vol. 5 No. 1, pp. 87-108.

Kulendran, N. and Wilson, K. (2000), "Modelling business travel”, Tourism Economics, Vol. 6 No. 1, pp. 47-59.

Kulendran, N. and Witt, S. (2003), "Forecasting the demand for international business tourism", Journal of Travel Research, Vol. 41 No. 3, pp. 265-71.

Landeta, J. (2006), "Current validity of the Delphi method in social sciences", Technological Forecasting \& Social Change, Vol. 73 No. 5, pp. 467-82.

Lin, V. and Song, H. (2015), "A review of Delphi forecasting research in tourism", Current Issues in Tourism, Vol. 18 No. 12, pp. 1099-131.

Lu, J. and Peeta, S. (2009), "Analysis of the factors that influence the relationship between business air travel and videoconferencing”, Transportation Research Part A: Policy and Practice, Vol. 43 No. 8, pp. 709-21.

Marcucci, E. and Gatta, V. (2012), "Dissecting preference heterogeneity in consumer stated choices", Transportation Research Part E: Logistics and Transportation Review, Vol. 48 No. 1, pp. 331-9.

Marques, J. and Santos, N. (2016), "Developing business tourism beyond major urban centres: the perspective of local stakeholders", Tourism and Hospitality Management, Vol. 22 No. 1, pp. 1-15.

Marques, J. and Santos, N. (2017a), "Business tourism development: a Portuguese perspective", Cuadernos de Turismo, Vol. 40 No. 40, pp. 423-37.

Marques, J. and Santos, N. (2017b), "Tourism development strategies for business tourism destinations: case study in the Central Region of Portugal", Tourism: An International Interdisciplinary Journal, Vol. 65 No. 4, pp. 437-49, available at: http://hrcak.srce.hr/191475

Mason, K. (2002), "Future trends in business travel decision making", Journal of Air Transportation, Vol. 7 No. 1, pp. 47-68.

Nicula, V. and Elena, P. (2014), "Business tourism market developments", Procedia Economics and Finance, Vol. 16, pp. 703-11.

O'Connell, J. and Williams, G. (2005), "Passengers' perceptions of low cost airlines and full service carriers: a case study involving Ryanair, Aer Lingus, Air Asia and Malaysia Airlines”, Journal of Air Transport Management, Vol. 11 No. 4, pp. 259-72. 
Pablo-Romero, M. and Molina, J. (2013), "Tourism and economic growth: a review of empirical literature", Tourism Management Perspectives, Vol. 8, pp. 28-41.

PENT (2007), "Plano Estratégico Nacional de Turismo para o desenvolvimento do turismo em Portugal", Ministério da Economia e da Inovação. Turismo de Portugal Lisboa, available at: www.observatorio.pt/ download.php?id=685 (accessed 10 January 2019).

Reitsamer, B. and Brunner-Sperdin, A. (2017), "Tourist destination perception and well-being: what makes a destination attractive?", Journal of Vacation Marketing, Vol. 23 No. 1, pp. 55-72.

Reshetnikova, N. (2017), "The internationalization of the Meetings. Incentives-, Conventions- and Exhibitions- (MICE) industry: Its influences on the actors in the tourism business activity", Journal of Economics and Management, Vol. 27 No. 1, pp. 96-113, doi: 10.22367/jem.2017.27.06.

Rowe, G. and Wright, G. (2001), "Expert opinions in forecasting: role of the Delphi technique", in Armstrong, J.S. (Ed.), Principles of Forecasting: A Handbook of Researchers and Practitioners, Kluwer Academic Publishers, Boston, MA, pp. 125-44.

Smagina, N., Magomedov, M. and Buklanov, D. (2017), "Sustainable competitive advantage of the international business tourism on the regional level", in Popkova, E. (Ed.), Overcoming Uncertainty of Institutional Environment as a Tool of Global Crisis Management. Contributions to Economics, Springer, Cham.

Tan, D. and Tsui, K. (2017), "Investigating causality in international air freight and business travel: the case of Australia", Urban Studies, Vol. 54 No. 5, pp. 1178-93.

Tichaawa, T. (2017), "Business tourism in Africa: the case of Cameroon", Tourism Review International, Vol. 21 No. 2, pp. 181-192.

Tsui, W., Balli, F., Tan, D., Lau, O. and Hasa, M. (2018), "New Zealand business tourism: exploring the impact of economic policy uncertainties", Tourism Economics, Vol. 24 No. 4, pp. 386-417.

Turismo de Portugal (2019), "Travel Bl", Turismo em Portugal 2018, Lisboa, available at: https://travelbi. turismodeportugal.pt/pt-pt/Documents/Turismo\%20em\%20Portugal/turismo-emportugal-2018.pdf (accessed 12 March 2019).

Turner, L. and Witt, S. (2001), "Factors influencing demand for international tourism: tourism demand analysis using structural equation modelling revisited", Tourism Economics, Vol. 7 No. 1, pp. 21-38.

UNWTO (2019a), "World Tourism Organization", Statistics, available at: https://statistics.unwto.org/ (accessed 20 April 2019).

UNWTO (2019b), “World Tourism Organization”, The Travel \& Tourism Competitiveness Index 2017, World Tourism Barometer and Statistical Annex, January, Madrid, available at: www2.unwto.org/publication/unwtoworld-tourism-barometer-and-statistical-annex-january-2019 (accessed 20 April 2019).

Vengesayi, S., Mavondo, F. and Reisinger, Y. (2009), "Tourism destination attractiveness: attractions, facilities, and people as predictors”, Tourism Analysis, Vol. 14 No. 5, pp. 621-36.

Wootton, G. and Stevens, T. (1995), "Business tourism: a study of the market for hotel-based meetings and its contribution to Wales's tourism", Tourism Management, Vol. 16 No. 4, pp. 305-13.

WTTC (2019), "World Travel and Tourism Council", available at: www.wttc.org/economic-impact// (accessed 6 March 2019).

Ziglio, E. (1996), "The Delphi method and its contribution to decision making", in Adler, M. and Ziglio, E. (Eds), Gazing into the Oracle: The Delphi Method and Its Application to Social Policy and Public Health, Jessica Kingsley Publishers, Bristol, PA, pp. 3-33.

Zontek, E.L., Zontek, Z. and Szewczyk, I. (2018), "Identification of modern amenities in accommodation services. Analysis for Polish business tourism. New trends and issues", Proceedings on Humanities and Social Sciences, Vol. 5 No. 2, pp. 74-81. 